Tables Vol. I to X can be found in any issue till 2008 .

XI I La planification dans des nations du tiers monde ; bilan ritique.

2 La foi et les mœurs or Faith and Morals.

XII I Permanent non-Revolution.

2 Reflections on Durkheim.

XIII I Permanent non-Revolution (continued)

2 "A Sack of Potatoes" ?

XIV I The Political Elite, British and French.

2 Tantum Religio...

XV I Faith and Power.

2 Citoyens armés, prétoriens désarmés.

XVI I Observer's Analysis of Caste and Clientele.

2 From Madness to Mental Illness.

XVII I Structure and Interest.

2 Professions avec ou sans compétence.

XVIII I Might and Rite.

2 Whither the unwithered state.

XIX I Le prix moral de I'égalité.

2 Sociologie de la science.

XX I Hidden God, visible cleric.

2 Auslese in der Kultur geschichte.

XXI I Capitalism and the Rite of Religion.

2 Racines aristocratiques de la démocratie.

XXII I Michels and his critics.

2 Comprendre les cas extrêmes.

XXIII I Soziologische Selbstbespiegelung.

XXIV I Overt and Covert Politics clients, factieux, brigands.

2 Unnecessary Revolution.

XXV I Auslese durch Erziehung oder Technik?

2 Tending the roots : nationalism and populism.

XXVI I Nécessité de la vie politique.

2 Le mythe du mythe.

XXVII I Caste, feudality, nation.

2 Vin nouveau, vieilles outres

XXVIII I Über politisches Handeln.

2 Liberalism: a communitarian critique.

XXIX I (a) Le pouvoir et I'entreprise.

(b) An enquiry into patronage.

2 "Homes fit for heroes".

XXX I Allégeances en exil.

2 Sentiments moraux, effets sociaux.

XXXI I New challenges to justice.

2 Regional autonomy : marginalization, integration \& democracy.
XXXII I The puzzling scope of rationality.

2 Citizenship and social bonds.

XXXIII I Society and democracy in Eastern Europe.

2 The social construction of selfinterest.

XXXIV I The weight of the past.

2 Our Scottish Ancestors.

XXXV I Max Weber : Semantic Distortions.

2 L'étranger et l'infidèle.

XXXVI I Threats and bluffs in East European transitions.

2 L'âme russe.

XXXVII I Postcommunism : negation of the negation.

2 Exclus et prolétaires.

XXXVIII I Gehen, Bleiben, Kommen.

2 Interdits comparés.

XXXIX I Making credible commitments.

2 Présence de I'au-delà.

$\mathrm{XL}$ I Lustration.

2 Durkheimian legacies.

XLI I The power of language and the language of power.

2 Scale and time in sociological explanation.

XLII I $40^{\mathrm{e}}$ anniversaire.

2 When regimes implode.

3 L'interpersonnel et la rationalité des acteurs.

XLIII I Priorities of social justice.

2 Études critiques.

3 Mysticism and ascetism.

XLIV I China in Transition

2 Études critiques

3 Citizenship: National and Transnational.

XLV I Attributions et exclusions

2 Beyond ethnicity and nationality

3 The state of the Art.

XLVI I Religion and Society.

2 State of emergency and the emergence of the state

3 State of the Art

XLVII I Multiple axialities, multiple modernities

2 Markets in context

3 State of the Art.

XLVIII I Historical roots of institutional developments

2 Debate on money

3 State of the Art

XLIX I Dictature and war

2 Creativity of social movements

3 Critical studies

Volumes 1-29 are available from Swets and Zeitlinger, Heereweg 347, PO Box 810, 2160 
I MPR I M ER I E F. PA I L LAR T

A B B E V I L L E

ISSN $0003-9756$

Le gérant : JACQUES LAUTMAN

Printed in France 


\section{Revue française de sociologie}

publiée avec le concours du

CENTRE NATIONAL DE LA RECHERCHE SCIENTIFIQUE

59-61, rue Pouchet 75849 Paris Cedex 17 - Tél. : 0140251188

La transmission culturelle : Sylvie OCTOBRE

tels parents, tels enfants? Yves JAUNEAU

Aux sources de la sociologie du travail Lucie TANGUY

en France

Travailler en prison Fabrice GUILBAUD

Le magistrat, le maire Anne-Cécile DOUILLET et la sécurité publique Jacques de MAILLARD

NOTE CRITIQUE

Une nouvelle adolescence Olivier GALLAND

LES LIVRES

Abonnements/Subscriptions (2009) :

L'ordre et le paiement sont à adresser directement à :

Please send order and payment to:

Éditions OPHRYS - 25, rue Ginoux - 75015 Paris

0145783390

France :

Particuliers : $85 €$ (4 numéros trimestriels)

Institutions : $95 €$ (4 numéros trimestriels)

Institutions : $120 €$ (4 numéros trimestriels + supplément en anglais)

Étudiants : $\quad 65 €$ (4 numéros trimestriels)

Étranger/Abroad :

$125 €$ (4 numéros + supplément en anglais/

four quarterly issues + the English selection)

Vente au numéro/Single issue:

Le numéro trimestriel/for each quarterly issue : $23 €$

(jusqu'en 2008/until 2008)

Le numéro trimestriel/for each quarterly issue : $25 €$

(à partir de 2009/from 2009)

La sélection anglaise/for the English selection : $30 €$

www.rfs-revue.com 


\section{Revue française de sociologie}

publiée avec le concours du

CENTRE NATIONAL DE LA RECHERCHE SCIENTIFIQUE

59-61, rue Pouchet 75849 Paris Cedex 17 - Tél. : 01402511 87/88

JANVIER-MARS 2009, 50-1

ISBN 978-2-7080-1233-2

Éditorial : Qu'est-ce qui fonde la légitimité de l'évaluation scientifique ? Consécration des poètes contemporains Sébastien DUBOIS

Le comptage de la délinquance : Renée ZAUBERMAN deux sources statistiques Philippe ROBERT Sophie NÉVANEN Emmanuel DIDIER

Le sida aux Antilles et le multipartenariat sexuel Stéphanie MULOT

L'affaire Pechiney saisie par la presse Camille HAMIDI

Protection du patrimoine parisien et François-Mathieu démocratie participative POUPEAU

Mesurer la confiance, dénoncer la défiance : Jacques RODRIGUEZ deux économistes au chevet Jean-Michel du modèle social français WACHSBERGER

LES LIVRES

Abonnements/Subscriptions (2009) :

L'ordre et le paiement sont à adresser directement à :

Please send order and payment to:

Éditions OPHRYS - 25, rue Ginoux - 75015 Paris

0145783390

France :

Particuliers : $85 €$ (4 numéros trimestriels)

Institutions : $95 €$ (4 numéros trimestriels)

Institutions : $120 €$ (4 numéros trimestriels + supplément en anglais)

Étudiants : $\quad 65 €$ (4 numéros trimestriels)

Étranger/Abroad :

$125 €$ (4 numéros + supplément en anglais/

four quarterly issues + the English selection)

Vente au numéro/Single issue :

Le numéro trimestriel/for each quarterly issue : $23 €$

(jusqu'en 2008/until 2008)

Le numéro trimestriel/for each quarterly issue : $25 €$

(à partir de 2009/from 2009)

La sélection anglaise/for the English selection : $30 €$

www.rfs-revue.com 


\section{Annales}

\section{Histoire, Sciences Sociales}

\section{Histoire et philosophie}

$n^{\circ} 1$

janvier-février 2009

\section{Sommaire}

Étienne Anheim, Antoine Lilti et Stéphane Van Damme

Quelle histoire de la philosophie?

\section{Frontières}

Maria Pia Donato

Les doutes de l'Inquisiteur. Philosophie naturelle, censure et théologie à lépoque moderne

Jean-Pierre CAVAILlÉ

Libérer le libertinage. Une catégorie à lépreuve des sources

\section{Concepts}

Martin Mulsow

Qu'est-ce qu'une constellation philosophique ? Propositions pour une analyse des réseaux intellectuels Silvia Caianiello

L'enjeu épistémologique de la notion d'époque entre organisme et système au XIX ${ }^{e}$ siècle

\section{Débats}

Catherine KÖNIG-PralONG

L'histoire de la philosophie médiévale depuis 1950 : méthodes, textes, débats

Antoine LILTI

Comment écrit-on l'histoire intellectuelle des Lumières ? Spinozisme, radicalisme, et philosophie

Sylvain PIRON

Une anthropologie historique de la scolastique (note de lecture)

\section{Histoire intellectuelle (comptes rendus)}

Résumés / Abstracts

Livres reçus

\section{Rédaction}

54 bd Raspail 75006 Paris •.Tél.: 0149542377 • annales@ehess.fr

\section{Abonnement}

Armand Colin abonnements: 5, rue Laromiguière • 75240 Paris Cedex 05 • Tél.: 0820065095 (France) • Tél.: 33140464989 (international). Fax: 33 (0)140464993 • infos@armand-colin.com

\section{Vente au numéro}

Prix d'un numéro simple: $17 €$ - Prix d'un numéro double: $25 €$

En librairie et en ligne: diffusion Dif'Pop • 21ter, rue Voltaire · 75011 Paris

Tél.: 33 (0)1 40242131 - Fax: 33 (0)1 40241588 • www.difpop.com

Aux Éditions de l'EHESS: vente sur place et par correspondance

Facturation: 33 (0)153105356.Fax: 33 (0)144070889 • editions-vente@ehess.fr 


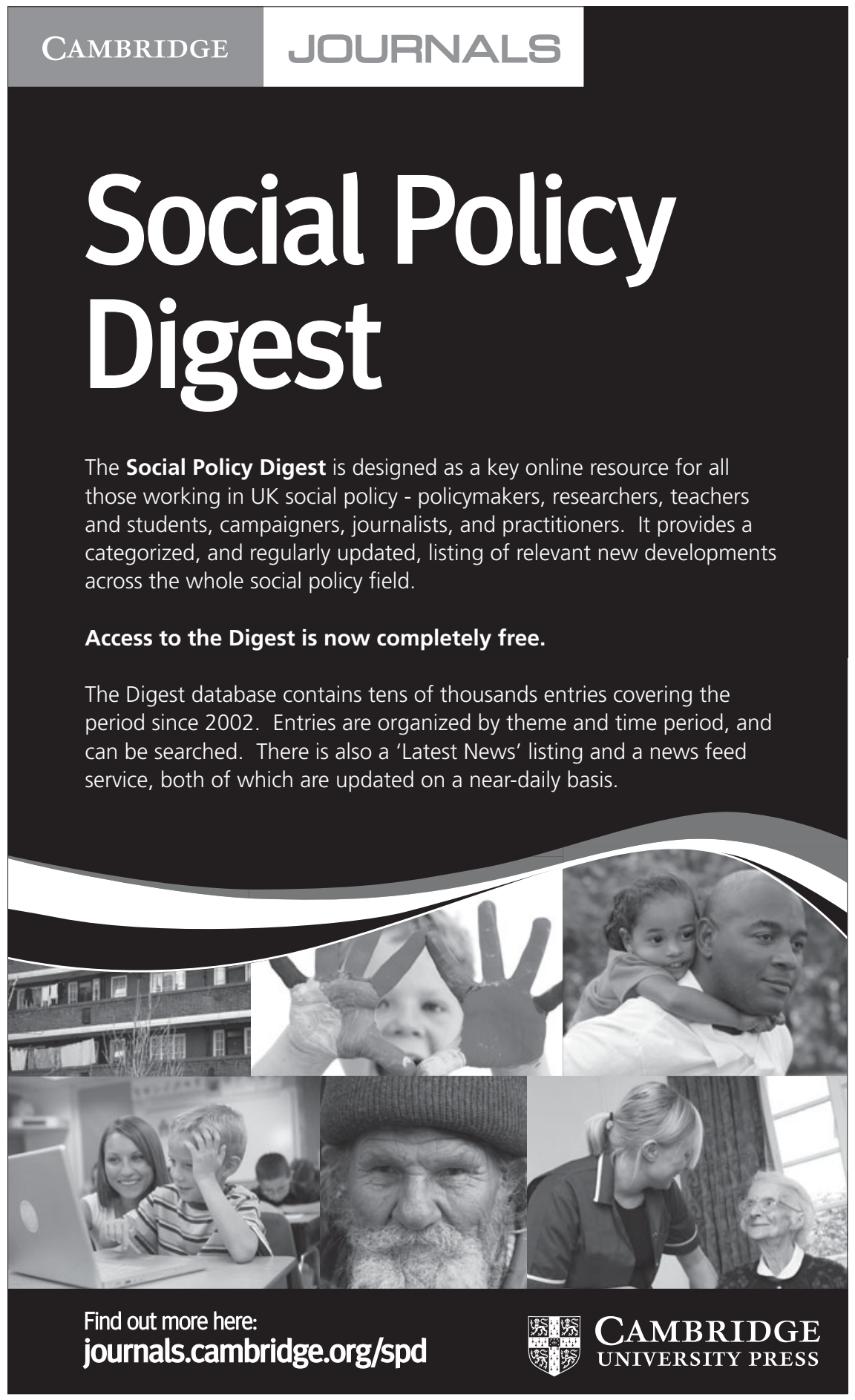




\section{JDURNALS}

\section{Knowledge is no longer shelved}

The Cambridge Journals Digital Archive

contains more than 160 journals, more than

3 million pages and more than 8 million

linked references. Knowledge is now more visible and more searchable than ever.
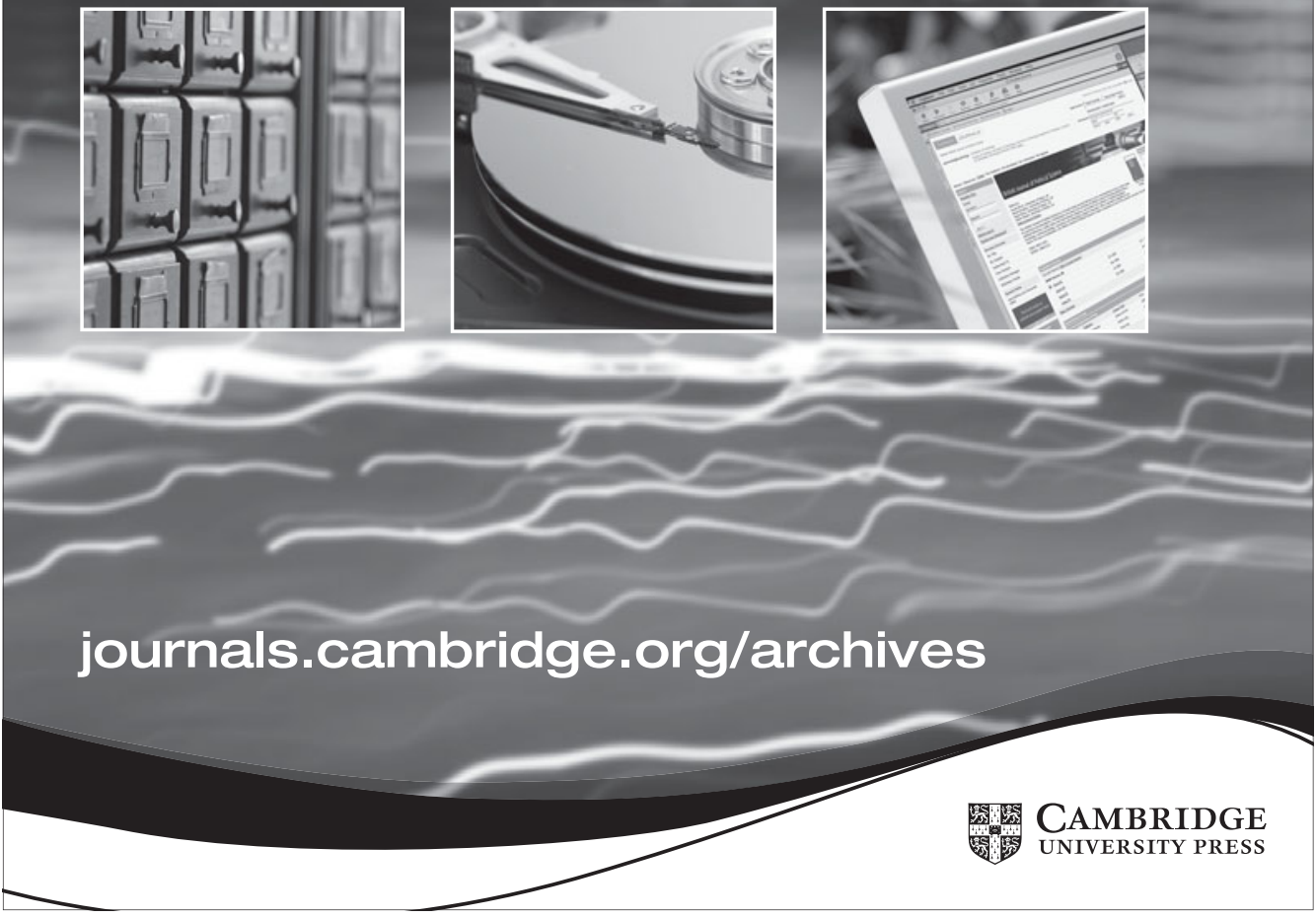


\section{CAMBRIDGE JURNALS}

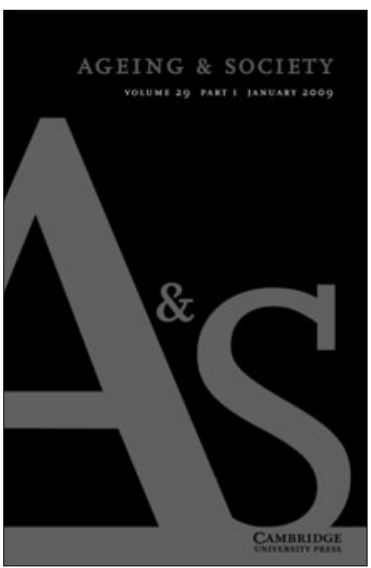

Ageing \& Society

is available online at:

http://journals.cambridge.org/aso

To subscribe contact Customer Services

in Cambridge:

Phone +44 (0)1223 326070

Fax +44 (0)1223 325150

Email journals@cambridge.org

in New York:

Phone (845) 3537500

Fax (845) 3534141

Email

subscriptions_newyork@cambridge.org

\section{AGEING \& SOCIETY}

The Journal of The Centre for Policy on Ageing and The British Society of Gerontology

\section{Editor}

Tony Warnes, University of Sheffield, UK

Ageing \& Society is an interdisciplinary and international journal devoted to publishing papers which further the understanding of human ageing in the wider social and cultural context. Ageing \& Society features an extensive book review section and a regular updating on specified research areas.

\section{Price information is available at: http://journals.cambridge.org/aso}

\section{Free email alerts}

Keep up-to-date with new material - sign up at http://journals.cambridge.org/alerts

For free online content visit: http:l/journals. cambridge.org/aso 


\section{CAMBRIDGE JOURALS}

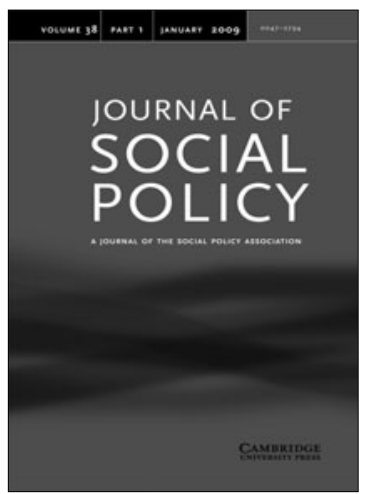

Journal of Social Policy

is available online at:

journals.cambridge.org/jsp

To subscribe contact Customer Services

in Cambridge:

Phone $+44(0) 1223326070$

Fax $+44(0) 1223325150$

Email journals@cambridge.org

in New York:

Phone (845) 3537500

Fax (845) 3534141

Email

subscriptions_newyork@cambridge.org

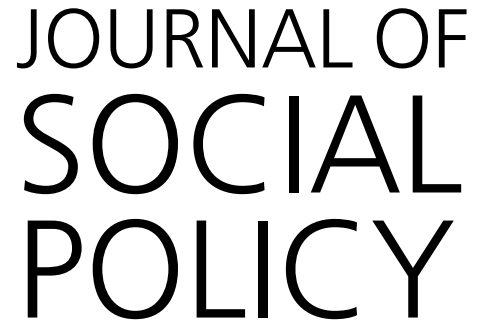

\section{Editors}

Tania Burchardt, London School of Economics and Political Science, UK

Hartley Dean, London School of Economics and Political Science, UK

The Journal of Social Policy carries high quality articles on all aspects of social policy. It places particular emphasis upon articles which seek to contribute to debates on the future direction of social policy, to present new empirical data, to advance theories, or to analyse issues in the making and implementation of social policies.

The Journal of Social Policy is part of the 'Social Policy Package', which also includes Social Policy and Society.

Price information is available at: journals.cambridge.org/jsp

\section{Free email alerts} Keep up-to-date with new material sign up at journals.cambridge.org/register

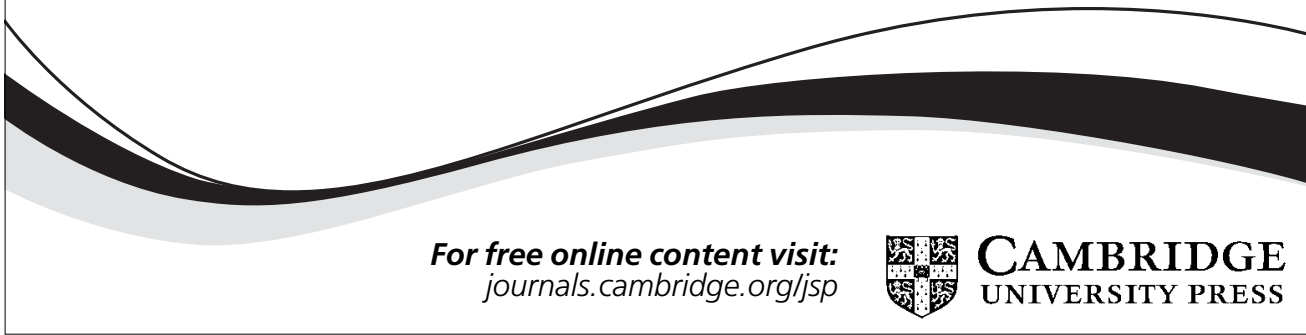




\section{CAMBRIDGE JURNALS}

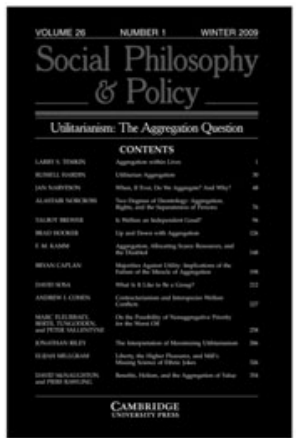

Social Philosophy and Policy is available online at:

http://journals.cambridge.org/soy

To subscribe contact Customer Services

in Cambridge:

Phone $+44(0) 1223326070$

Fax +44 (0)1223 325150

Email journals@cambridge.org

in New York:

Phone +1 (845) 3537500

Fax +1 (845) 3534141

Email

subscriptions_newyork@cambridge.org

\section{Social Philosophy \& Policy}

Published for The Social Philosophy and Policy Foundation

\section{Editor}

Ellen Frankel Paul, Bowling Green State University, USA Associate Editors

Fred D. Miller, Jr., Bowling Green State University, USA Jeffrey Paul, Bowling Green State University, USA

Social Philosophy and Policy is an interdisciplinary journal with an emphasis on the philosophical underpinnings of enduring social policy debates. The issues are thematic in format, examining a specific area of concern with contributions from scholars in philosophy, economics, political science and law.

Price information is available at: http://journals. cambridge.org/soy

Free email alerts

Keep up-to-date with new material - sign up at http://journals.cambridge.org/alerts 


\section{T A B L E Q U I N Q U E N N A L E \\ D E S T O M E X L V À X L I X}

\section{$2004-2008$}

AdLoff Frank and Steffen MaU

Giving Social Ties, Reciprocity in Modern Society, XLVII .

AkTURK Sener

Incompatible Visions of Supra-nationalism: Institutions of National Identity in Turkey and the European Union, XLVIII2.

Alligier-Otanian Sandrine

Durkheim et l'épistémologie des pratiques sociales, $\mathrm{XLVI}_{3}$.

Secularism and secularity, $\mathrm{XLIX}_{3}$.

ARJomand Saïd Amir

Coffeehouses, guilds and oriental despotism. Government and civil society in late $17^{\text {th }}$ to early $18^{\text {th }}$ century Istanbul and Isfahan, and as seen from Paris and London, XLVI.

Southern theory: an illusion, $\mathrm{XLIX}_{3}$.

ARnason Johann P.

Global paths to modernity, $\mathrm{XLVI}_{3}$.

AzManova Albena

The mobilisation of the European left in the early $21^{\text {st }}$ century, XLV2.

Baehr Peter

Social extremity, communities of fate, and the sociology of SARS, XLVI2.

BARbALET Jack M.

Emotional Payoffs of Ritual, XLVII 3 .

BARgheER Stefan

The Fools of the Leisure Class. Honor, Ridicule, and the Emergence of Animal Protection Legislation in England, 1740-1840, XLVIII.

Battini Michèle and Nadia Urbinati Divorce within modernity, XLVIII 3 .

Beck Jan Mansvelt and Jan D.

Markusse

Basque Violence: a Reappraisal of Culturalist Explanations, XLIXI.
BECKERT Jens

Political and social interests in the transfer of property, XLVI2.

The Longue Durée of Inheritance Law, XLVIIII.

Beim Aaron and Gary Alan Fine

Trust in Testimony: the Institutional Embeddedness of Holocaust Survivor Narratives, XLVIII I .

Bellah Robert N.

What is Axial about the Axial Age?, XLVII.

Benson Rodney

The political shaping of the media, $\mathrm{XLVI}_{3}$.

BoËNE Bernard

Method and Substance in the Military Field, XLIX 3 .

Brewer John D.

Putting C. Wright Mills in his place, $\mathrm{XLV}_{3}$.

Caldwell Melissa L.

Cosmopolitan anxieties, $\mathrm{XLIX}_{3}$.

Calhoun Craig

A secular age, $\mathrm{XLIX}_{3}$.

Casanova José

Liberal modernity, Catholicism, Islam, $\mathrm{XLIX}_{3}$.

Case Holly

Ethnicity enacted, $\mathrm{XLVIII}_{3}$.

Charle Christophe

Les intellectuels : le Sonderweg britannique, $\mathrm{XLVIII}_{3}$.

Chenu Alain and Laurent Lesnard Time Use Surveys: a Review of their Aims, Methods, and Results, $\mathrm{XLVII}_{3}$.

Chibber Vivek

The return of imperialism to social science, $\mathrm{XLV}_{3}$. 
Chorev Nitsan

States still matter, $\mathrm{XLVIII}_{3}$.

Clark Samuel

Human intentionality in the functionalist theory of social change: the role of French provincial intendants, XLVI2.

Davie Grace

Religion in Europe in the $21^{\text {st }}$ Century: the Factors to Take into Account, $\mathrm{XLVII} 2$.

DiETz Hella

Opposition der Siebziger in Polen. Ein Beitrag zur Integration neuerer Theorien sozialer Bewegungen, XLIX2.

The defeat of solidarity, $\mathrm{XLIX}_{3}$.

DodD Nigel

Laundering "Money": on the Need for Conceptual Clarity within the Sociology of Money, XLVI3.

On Simmel's Pure Concept of Money: A Response to Ingham, XLVIII2.

Dumouchel Paul

Trust as an Action, $\mathrm{XLVI}_{3}$.

Rejoinder, $\mathrm{XLVI}_{3}$.

DunN John

Democracy, $\mathrm{XLIX}_{3}$.

ERTMAn Thomas

A noble substitute for politics, $\mathrm{XLVIII}_{3}$.

Espeland Wendy Nelson and Mitchell L. STEVEns

A Sociology of Quantification, $\mathrm{XLIX}_{3}$.

FAIsT Thomas

Towards a political sociology of transnationalization. The state of the art in the migration research, $\mathrm{XLV}_{3}$.

FAVELl Adrian

Euroclash, $\mathrm{XLIX}_{3}$.

Ferrara Alessandro

On rationality and recognition, $\mathrm{XLIX}_{3}$.

Fine Gary Alan

Why and Why not?, $\mathrm{XLVII}_{3}$.

Fine Gary Alan and Aaron Beim

Trust in Testimony: the Institutional Embeddedness of Holocaust Survivor Narratives, XLVIII I.
Finger Anja

After Slumber: the sociological study of sleep, $\mathrm{XLVI}_{3}$.

Forsé Michel et Caroline Guibet

LAFAYE

La démocratie participative et les devoirs du citoyen, XLIX2.

Frade Carlos

The Regulations of Honour: an Attempt at a Weberian and Anthropological Enquiry through the Prism of a Spanish Trading Group, XLVII2.

Freeden Michael

Steel in the velvet glove, $\mathrm{XLVII}_{3}$.

Frère Bruno

Incertitudes sur l'habitus, $\mathrm{XLVI}_{3}$.

GambetTa Diego

The Structure of the Game and the Payoffs, $\mathrm{XLVI}_{3}$.

GANDHI Jennifer

Dictatorial Institutions and their Impact on Economic Growth, XLIXI .

Goodwin Jeff

How not to Explain Terrorism, $\mathrm{XLVII}_{3}$. On terrorism, $\mathrm{XLIX}_{3}$.

Gorski Philip S.

Comment on Sigrun Kahl, XLVI2.

Gremy Jean-Paul

Une enquête au début du $\mathrm{X}^{\mathrm{e}}$ siècle : le questionnaire synodal de Réginon de Prüm, XLIX2.

Guibet Lafaye Caroline et Michel Forsé

La démocratie participative et les devoirs du citoyen, XLIX2.

Gurov Boris

Modélisation analytique de l'action, XLVIII2.

Haglund Ladawn and Steven Lukes Power and Luck, XLVII.

Haines Valerie A.

The sociology's heritage, $\mathrm{XLV}_{3}$.

Halliday Fred

Orientalism, Empire and Eccentricity, $\mathrm{XLVII}_{3}$. 
Halsey Albert A.

Selecting the elites, $\mathrm{XLIX}_{3}$.

HANn Christopher

"Le regard éloigné". Eurasia in the perspective of Jack Goody, $\mathrm{XLV}_{3}$.

The anthropology of christianity per se, $\mathrm{XLVIII}_{3}$.

HART Keith

The world in time-space, $\mathrm{XLVIII}_{3}$.

HÉnAfF Marcel

Lévi-Strauss et le principe de réciprocité, XLIX2.

Hollstein Bettina

Un monde commun?, $\mathrm{XLV}_{3}$.

Wirtschaftsanthropologie, $\mathrm{XLIX}_{3}$.

Huebner Daniel R.

Toward a Sociology of the State and War: Emil Lederer's Political Sociology, XLIXI.

Hunter Wade Robert

Modernization and private interests, $\mathrm{XLV}_{3}$.

\section{INGHAM Geoffrey}

The specificity of money, XLVIII2.

ISRAËL Liora

Penser la coordination des acteurs dans un monde pluriel, $\mathrm{XLVII}_{3}$.

JaCOBsson Kerstin

Moral disturbances in society,

$\mathrm{XLIX}_{3}$.

JANMAAT Jan Germen

Civic Culture in Western and Eastern

Europe, $\mathrm{XLVII}_{3}$.

JoAs Hans

Antisecularism, $\mathrm{XLIX}_{3}$.

KAHL Sigrun

The Religious Roots of Modern Poverty Policy: Catholic, Lutheran, and Reformed Protestant Traditions Compared, XLVII.

Kaspersen Lars Bo and Johannes

LINDVALL

Why No Religious Politics? The Secularization of Poor Relief and Primary Education in Denmark and Sweden, XLIXI.
Kaviraj Sudipta

On the enchantment of the state, XLVI2.

An Outline of a Revisionist Theory of Modernity, $\mathrm{XLVI}_{3}$.

Khosrokhavar Farhad

Terrorisme et missions suicide, $\mathrm{XLVI}_{3}$.

Kimmerling Baruch

The Exhaustion of the Primary Zionist Program, XLVIII .

KNÖBL Wolfgang

Of Contingencies and Breaks: the US American South as an Anomaly in the Debate on Multiple Modernities, XLVIII.

Koenig Matthias

Historical sociology, Limitations and Perspectives, $\mathrm{XLVII}_{3}$.

KuMAR Krishan

Dilemmas and contradictions of power, $\mathrm{XLVI}_{3}$.

Global Civil Society, XLVIII 3 .

Kurasawa Fuyuki

A cosmopolitanism from below: alternative globalization and the creation of a solidarity without bounds, XLV2.

LAITIN David D.

Integration of research and theory in the perspective of John Goldthorpe, $\mathrm{XLV}_{3}$.

Lannoy Pierre et Coline Ruwet

Autorité de chaire et modèle de chair. L'influence respective de G. Simmel et W.I. Thomas sur "La ville" de Robert Park, XLV I .

LaUtman Jacques

Exil et désassimilation, $\mathrm{XLVI}_{3}$.

On the link between micro and macro, $\mathrm{XLVII}_{3}$.

Interdisciplinarity in progress: Dominique Raynaud's contribution, $\mathrm{XLVIII}_{3}$.

LEDERER Emil

On the Sociology of World War, XLVII2.

LESNARD Laurent and Alain CHENU

Time Use Surveys: a Review of their Aims, Methods, and Results, XLVII 3 . 
L'estrange Sean

Religion, Authority and Rule, XLVIII2.

LindVALL Johannes and Lars Bo

KASPERSEN

Why No Religious Politics? The Secularization of Poor Relief and Primary Education in Denmark and Sweden, XLIXI.

Livet Pierre

Wittgenstein pour les sociologues, $\mathrm{XLVIII}_{3}$.

\section{LOISON Laurence}

La famille-providence au Portugal. Faire face aux conséquences du chômage, XLV2.

LONER Enzo

The Importance of Having a Different Opinion: Europeans and GM foods, XLIXI.

\section{LOYaL Steven}

Eurostars and eurocities, XLIX $_{3}$.

Lukes Steven and Ladawn HAGLund Power and Luck, XLVII.

Makropoulos Michael

Kontingenz. Aspekte einer theoretischen Semantik der Moderne, $\mathrm{XLV}_{3}$.

Manzo Gianluca

Le modèle du choix éducatif interdépendant, XLVIIII.

Towards an analytical understanding of terrorism, XLVIII 3 .

Marangudakis Manussos

The Social Sources and Environmental Consequences of Axial Thinking: Mesopotamia, China, and Greece in Comparative Perspective, XLVII I.

Markusse Jan D. and Jan Mansvelt BECK

Basque Violence: a Reappraisal of Culturalist Explanations, XLIXI.

Marquis Nicolas

Questions de respect, XLIXI.

Mastnak Tomas

The reinvention of Civil society in Eastern Europe: through the looking glass of democracy, XLVI2.
MaU Steffen and Frank AdLoff

Giving Social Ties, Reciprocity in Modern Society, XLVIII.

Mears Ashley

The ambivalence of consumption, $\mathrm{XLVIII}_{3}$.

\section{Melossi Dario}

The consequence of mass imprisonment, XLVIII 3 .

\section{Mercklé Pierre}

Utopie ou "sciences sociales " ? Réceptions de l'œuvre de Charles Fourier au $\mathrm{XIX}^{\mathrm{e}}$ siècle, $\mathrm{XLV}_{\mathrm{I}}$.

Merklen Denis

Combattre pour la solidarité, XLIX 3 .

Mirowski Philip

Coming to Terms with Neoliberalism, $\mathrm{XLVII}_{3}$.

Mistzal Barbara A.

Ambiguities and clichés in the debate about public intellectuals, XLVIII2.

\section{Mitchell Timothy}

The work of economics, how a discipline makes its world, XLVI2.

Molotch Harvey

Telling about society, XLIX $_{3}$.

MORNING Ann

Newcomers in Italy, XLVIII 3 .

Neuberg Samuel

Mondes imbriqués, $\mathrm{XLVIII}_{3}$.

Nissen Sylke

Hybridräume. Zum Wandel von Öffentlichkeit und Privatheit in der Stadt, XLIX2.

Ogien Albert

Confiance en régime démocratique et en régime totalitaire, $\mathrm{XLVI}_{3}$.

Okely Judith Patterns of exclusion, XLIX $_{3}$.

Origgi Gloria

On Trustworthiness, $\mathrm{XLVI}_{3}$.

PAXTON Robert O.

Fascists, $\mathrm{XLVI}_{3}$.

Petrunov Georgi

Organized crime and social transformation in Bulgaria, XLVII2. 
Pettenkofer Andreas

Weber's Theory of Radical Movements:

A Reappraisal, XLIX2.

Bearing witness against sin, $\mathrm{XLIX}_{3}$.

Pharo Patrick

Les causes, les raisons et la morale, XLVIII.

PlatT Jennifer

Sociology's longue durée, $\mathrm{XLVIII}_{3}$.

Plehwe Dieter

Neoliberal hegemony, XLVI 3 .

Pollack Detlef

Support for democracy in Eastern and

Western Germany: an attempt to explain the differences, XLV2.

Sacred and secular, $\mathrm{XLVII}_{3}$.

PrZeworski Adam

The last instance: are institutions the primary cause of economic development?, XLV2.

RAYNER Jeremy

Neoliberalism and the Politics of Microenterprise Development in Cairo, $\mathrm{XLVII}_{3}$.

Rile HaYward Clarissa

Space and the state in the time of global capital, $\mathrm{XLVI}_{3}$.

Robertson Alexander F.

Regeneration in Rural Catalonia, XLIX2.

Root Michael

Interpretation updated, $\mathrm{XLV}_{3}$.

RössEL Jorg

Social Change and Violent Crime, $\mathrm{XLVIII}_{3}$.

RuAne Joseph and Jennifer TodD

The roots of intense ethnic conflict may not in fact be ethnic: categories, communities and path dependence, XLV2.

Runciman W. Gary

The diffusion of Christianity in the third century AD as a case-study in the theory of cultural selection, XLVI

Cultural Selection, Axiological Reasoning, and Paradiastole, XLVIII I.

Ruwet Coline et Pierre Lannoy

Autorité de chaire et modèle de chair.
L'influence respective de G. Simmel et W.I. Thomas sur "La ville" de Robert Park, XLVI.

Salvan Monica

Interactions identitaires, $\mathrm{XLVIII}_{3}$.

SCAFF Lawrence A.

Weber unbound, $\mathrm{XLVII}_{3}$.

Scheuerman William E.

Social Theory of Speed, $\mathrm{XLVII}_{3}$.

Schubert Hans-Joachim

Fünf soziologische Theorien der Demokratie, XLVII.

Sciulli David

Professions before professionalism, XLVIIII.

Silver Dan

Religion without Instrumentalization, $\mathrm{XLVII}_{3}$.

SMith Charles W.

Financial markets up close, XLVIII 3 .

Soysal Yasemin Nuhoglu

Diversity and Democratic Inclusion: in Defense of Conflict, $\mathrm{XLVII}_{3}$.

Sperber Dan

Claude Lévi-Strauss, a precursor?, $\mathrm{XLIX}_{2}$.

StAnley Jason

The mediation of power, $\mathrm{XLIX}_{3}$.

Steiner Philippe

L'héritage égalitaire comme dispositif social, XLVI I.

Organ transplantation and political issues: a rejoinder, $\mathrm{XLVI} 2$.

Stevens Mitchell L. and Wendy Nelson ESPELAND

A Sociology of Quantification, $\mathrm{XLIX}_{3}$.

STREeck Wolfgang

America and european self-understanding, $\mathrm{XLVIII}_{3}$.

SwEDBERG Richard

What has been accomplished in new economic sociology and where is it heading?, $\mathrm{XLV}_{3}$.

SzTompka Piotr

Cognition, Expectation, Action, $\mathrm{XLVI}_{3}$ 
TodD Jennifer and Joseph RuAnE

The roots of intense ethnic conflict may not in fact be ethnic: categories, communities and path dependence, XLV2.

Tuck Richard

The rise of rational choice, $\mathrm{XLVI}_{3}$.

Urbinati Nadia

A secular age, $\mathrm{XLIX}_{3}$.

Urbinati Nadia and Michèle Battini Divorce within modernity, $\mathrm{XLVII}_{3}$.

VAn Parijs Philippe

Europe's linguistic challenge, XLVI.

VARese Federico and Meir YaIsh

Resolute Heroes: the Rescue of Jews during the Nazi Occupation of Europe, XLVII.

Waldmann Peter

Die Kontingenz der Moderne, $\mathrm{XLIX}_{3}$.
WALDRON Jeremy

Dignity and Rank, XLVIII2.

WANG Junmin

State-Building as Market-Building in China, XLVII2.

Can China save socialism?, XLVIII 3 .

WitTrock Björn

Civilizations in Dispute, $\mathrm{XLVII}_{3}$.

WÖHRLE Patrick

Zwischen Rekonstruktion und Konstruktion, $\mathrm{XLIX}_{3}$.

Yaish Meir and Federico Varese

Resolute Heroes: the Rescue of Jews during the Nazi Occupation of Europe, XLVII.

Zelizer Viviana A.

Charting a new discipline, $\mathrm{XLVII}_{3}$. 